\title{
Tibet and China's 'National Minority' Policies
}

\section{by Michael C. Davis}

Michael C. Davis is a Professor in the University of Hong Kong, Faculty of Law. This article is a revised version of a paper he delivered at a conference on "Contested Terrain: China's Periphery and International Relations in Asia. The event was sponsored by the Foreign Policy Research Institute and the Reserve Officers Association in Washington, D.C. on November 4, 2011.

Abstract: China's hardline and repressive policies have often stood in the way of its acceptance on the international stage. This legacy has nowhere been more evident than with respect to its national minority policies applied in Tibet. While China long ago in the 1951 17-point Agreement agreed to provide autonomy to Tibetans it has never delivered on this promise, offering repression and assimilation instead. In nearly every diplomatic outing, as was especially evident in the lead up to the 2008 Beijing Olympics, China's Tibet policies have been an issue. With the 2007 UN Declaration on the Rights of Indigenous Peoples and the 2008 Tibetan Memorandum on Genuine Autonomy for the Tibetan People China surely has excellent guidance for a more humane policy to meet Tibetan concerns. With reference to its historical legacy and international standards, this paper encourages China to embrace such policy reform.

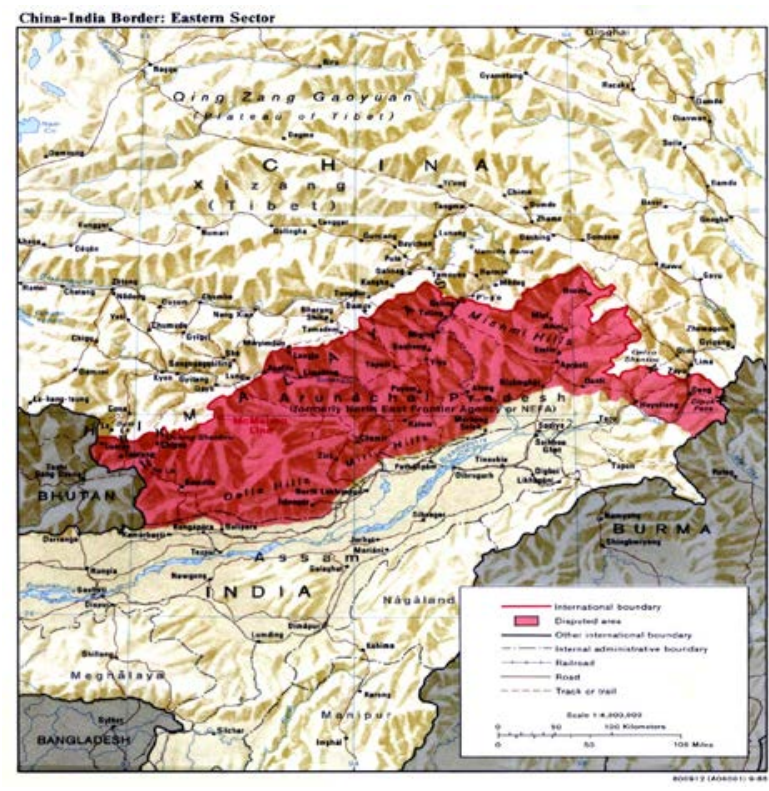

C hina has recently taken to labeling claims to peripheral territory as "core interest," as if such labeling might eliminate any competing claims While the past year has most notably seen the extension of such designation to regions beyond China's current control in the East and South China seas, Beijing has long taken such aggressive posture regarding occupied areas along its Western borders - especially in Tibet and the Uyghur areas of present-day Xinjiang. Each of these areas shares the status of being the homeland of a distinctive nationality with a separate language, culture and history. Both were occupied by the People's Republic of China (PRC) soon after its founding. While the Tibetan and Uyghur areas share in common aggressive and dismissive 
Chinese national minority policies and laws, their distinctive history and analytical posture make the coverage of one case, Tibet, a fruitful vehicle for exploring the implications of such nationality policies in the border regions more generally. After decades of Chinese posturing over foreign criticism and discussions with the exiled Tibetan leader, the Dalai Lama, the Tibetan case offers a telling example with

deep implications for Chinese foreign policy and assessing China's rise. The Tibet issue has been most directly of concern to China's immediate neighbor, India, but has also been a long-standing foreign policy concern in both the United States and Europe.

Superficially, the positions publicly taken by the Tibetan leadership in exile and the Chinese government appear to overlap considerably. ${ }^{1}$ The Dharamsala-based Government-in-Exile, under the Dalai Lama and its newly elected Kalon Tripa or Prime Minister, has long sought a renewed agreement granting Tibet genuine autonomy under the Chinese constitution. Proposals in this regard were formally submitted to the Chinese Government in the 2008 Tibetan Memorandum of Genuine Autonomy for the Tibetan People. ${ }^{2}$ As discussed below, the Chinese Government has likewise claimed to offer autonomy under its national minority laws. Such autonomy was first promised in respect to Tibet under a Seventeen-point Agreement reached between the PRC and the Dalai Lama in 1951. ${ }^{3}$

While China has since extended this autonomy promise in much more limited form to fifty-five designated national minorities, the Tibetan case of an historic nation on China's border has remained distinctive, as the only "national minority" with which the PRC has entered a bilateral agreement, promising a high degree of autonomy under an indigenous form of self-rule. The Tibet case shares only with the Uyghur case the status of a border nationality with historically distinct identity occupying a substantial portion of the territory currently ruled by the PRC. ${ }^{4}$ However, even the Uyghur do not possess a comparable agreement with the PRC government. The Seventeen-Point Agreement is widely believed to be the precursor to the "one country, two systems" model, with its "high degree of autonomy" now applied in Hong Kong and Macau, though the PRC government refuses to apply such Hong Kong model in Tibet. China's designation of fifty-five national minorities may aim at watering down the distinctive status and consequent obligations to the Tibetan people. Except for the Tibetans, Uyghur and Mongols, most minority

\footnotetext{
${ }^{1}$ Warren W. Smith, Jr. sees the two sides position as irreconcilable, as the central issue for Tibetans is the maintenance of Tibetan national identity and for the Chinese is to extinguish it. Warren W. Smith, Jr. China's Tibet: Autonomy or Assimilation (Boulder: Rowman and Littlefield, 2008) p. 279.

2 "Memorandum on Genuine Autonomy for the Tibetan People," Issued During the Eighth SinoTibetan Meeting, Nov. 4, 2008 (hereinafter "Tibetan Memorandum"). See also "Summary of the Memorandum on Genuine Autonomy for the Tibetan People," Dharamsala, India, Nov. 16, 2008. 3 Agreement of the Central People's Government and the Local Government of Tibet on Measures for the Peaceful Liberation of Tibet, May 23, 1951 (hereinafter "Seventeen-point Agreement").

${ }^{4}$ Tibetan areas currently occupied by the PRC make up roughly one-quarter of the present PRC. The other border nationality with substantial historical territory are the Mongols, though they have been reduced to a small minority in their region.
} 
nationalities are well within historically occupied Chinese territory and do not contest Chinese sovereignty.

Assessing Chinese public pronouncements and policies in light of international practices and standards may shed light on the current impasse and suggest possible alternatives going forward. This article addresses these Chinese policies and pronouncements in four parts: first, to set the tone, the stridency of China's recent public statements in the shadow of the 2008 Tibetan uprising and the Beijing Olympics; second, historical policies and current practice regarding the claimed provision of autonomy in Tibet; third, international standards regarding similarly situated indigenous populations; and fourth, recommendations regarding both Chinese policies and international foreign policy responses.

These recommendations will suggest the usefulness of the UN Declaration on the Rights of Indigenous Peoples as a framework and recommend the 2008 Tibetan Memorandum as a negotiating document that approximates these international standards. That recommendation will encourage a Chinese path that embodies the same spirit of inventiveness that it employed in creating the "one country, two systems" model now applied in Hong Kong and Macau and proposed for Taiwan. Such approach would enable China to shape a hybrid Tibetan solution that achieves the genuine autonomy embraced by the Tibetan Memorandum. The present analysis will not question the Tibetan exile government's formal stance on seeking autonomy versus independence, as this is a question with both substantive and strategic implications for Tibetans to decide.

A China that employs its rising power to repress indigenous and other internal populations and to intimidate its neighbors cannot help but pay an international price in suspicion and criticism for such aggressive stance. In this sense, Tibet has always been part of a larger policy concern that stretches beyond border security and internal resources. For China, seeing Tibet in limited security terms has been costly. With China's rise-and increasing global reach and potential — this price can only increase. In this sense, a viable solution to the Tibet problem may contribute to the effort to address wider peripheral concerns beyond Tibet, including even the Uyghur case. In moving forward in this regard China may also acquire a gentler less threatening face in its other international endeavors, reducing concerns currently associated with China's rise. Since the Chinese Government has rejected suggestions for a more moderate Tibet stance, realization of such policy objectives is likely to require international diplomatic engagement along similar policy lines for some time to come.

\section{The Current Impasse:}

\section{China's Reaction to Recent Tibetan Disturbances and Discussions}

The March 2008 Tibetan uprising, the subsequent Chinese crackdown and the international protests that followed the Olympic torch attracted considerable international concem, embarrassing Chinese officials as they prepared to host the 2008 Beijing Olympics. Beijing faced considerable international pressure to meet with the Dalai Lama's representatives and resolve 
this long-standing dispute. ${ }^{5}$ Though Chinese officials quickly moved into damage control, their subsequent actions and statements raise doubt about their intentions. The approach taken seemed aimed at putting out the immediate fire until the Olympics had passed and then bringing the Tibet problem under firm control. This mode of proceeding has long plagued Chinese policies in its periphery and has long attracted skepticism about its intentions in areas it identifies as core interests. Chinese officials quickly held an informal meeting with the Dalai Lama's representatives in Shenzhen near Hong Kong in May of 2008 and scheduled the seventh and eighth rounds in their ongoing formal dialogue to begin in July and late October that year, a time line just sufficient to get past the Beijing Olympics.

While international leaders and diplomats held out hope for substantive Sino-Tibetan dialogue, the marching orders for Chinese representatives were clearly more limited. They merely reiterated China's long-standing official position that Sino-Tibetan "contacts and dialogues were about the Dalai Lama's personal future, and not so-called "China-Tibet negotiation" or "dialogue between Han and Tibetan people." ${ }^{6}$ They insisted on three "stops" to: "stop activities aimed at splitting China, stop plotting and inciting violence and stop distupting and sabotaging the Beijing Olympic Games." This was later refined to "four non-supports": "not to support activities to disturb the upcoming Beijing Olympic Games, not to support plots to fan violent criminal activities, not to support and concretely curb the violent terrorist activities of the "Tibetan Youth Congress" and not to support any argument and activity to seek "Tibet independence" and split the region from the country." 7 The exiled Tibetan leadership has long met these conditions, and there is no record of the moderate Tibetan Youth Congress engaging in terrorist activities.

Though their earlier efforts in the 1950s to win over the Dalai Lama's support belie such claim, Chinese officials dismissively challenged the Dalai Lama's credentials to represent the Tibetan people, insisting that he must speak to the central government as a "common person." 8 They launched vociferous personal attacks on the Dalai Lama, labeling him a "wolf in monk's robes." All branches of the exile Tibetan community were lumped together and castigated as the "Dalai clique." Though these Chinese arguments are generally viewed with disdain around the globe, few foreign leaders have been willing to publicly confront the Chinese stand. Most substantive research to challenge the Chinese official position has been limited to private academic work with little official engagement.

In response to a Chinese request made at the July 2008 Sino-Tibetan meeting, the Dalai Lama's representatives in early November presented a formal Tibetan "Memorandum on Genuine Autonomy for the Tibetan People"

\footnotetext{
5 Willy Lam, "Beijing's Post-Olympics Shakedown in Xinjiang and Tibet," China Brief, Sept. 2008, pp. 2-4.

6 "Chinese official urges Dalai Lama to respond with sincerity after recent contact," Xinhua, Beijing, July 6, 2008.

${ }^{7}$ Ibid.

8 "China unwilling to broach Tibet with Dalai Lama," Indo-Asian News Service, Beijing, Tuesday, July 15, 2008.

${ }^{9}$ Michael C. Davis, "For Talks to Succeed China Must Admit to a Tibet Problem," YaleGlobal Online, May 16, 2008. http://yaleglobal.yale.edu/content/talks-succeed-china-must-admit-tibetproblem
} 
outlining their argument for autonomy under the Chinese Constitution. ${ }^{10}$ The Tibetan Memorandum sets forth Tibetan "aspirations" for genuine autonomy and self-government in eleven policy areas, including language, culture, religion, education, environmental protection, utilization of natural resources, economic development and trade, public health, internal public security, population migration and cultural, educational, and religious exchanges with other countries. Unfulfilled national ethnic autonomy policies enacted under Article 4 of the PRC Constitution already promise autonomy in nearly all of these areas. The exception may be those relating to immigration and external exchanges in the commercial and cultural areas, which appear instead to track policies similar to those applied under the PRC Constitution Article 31 "one country, two systems" formula.

There appears to be nothing in the law on national minority autonomy that would prohibit these extra protections in response to the unique local character, as allowed by the national minority law, discussed below. In the interest of self-government, the Tibetan Memorandum includes a specification that local laws within the scope of autonomy not be subject to central approval as is now required in minority areas under the Chinese national minority statute and that the terms of their agreement with the Central Government not be subject to the Central Government's unilateral amendment. The Tibetans appear to recognize that too much Central oversight and manipulation has lead to the failure of the current autonomy policies. They further proposed to unify into one autonomous region the thirteen contiguous Tibetan areas that China has designated under its national minority autonomy laws. The Tibetan Memorandum acknowledges the continuing application of the Chinese socialist system within Tibet, though one may doubt whether that economic system persist in China today.

Finally, the Tibetan Memorandum acknowledges the authority of the National People's Congress (NPC) and other organs of the Central Government and would accept application of the system of local people's congresses with locally chosen representatives within the Tibetan autonomous area. The Tibetan Memorandum was presented as a starting position for further negotiation. These proposals track the United Nations Declaration on the Rights of Indigenous Peoples that China supported in the UN General Assembly.

The Chinese response was quick and harsh. In an early November 2008 Chinese State Council press conference, Mr. Zhu Weiqun of the United Front Works Department attacked the Tibetan position as essentially camouflage for independence. ${ }^{11}$ The accompanying State Council Address likened the Tibetan notion of "genuine autonomy" to the "high degree of autonomy" allowed Hong Kong. The Tibetans were accused of seeking "half-independence," and "covert independence," though no explanation is given why the same language applied to Hong Kong means only autonomy. The State Council Address further accuses the exiled Tibetans of "colluding with such dregs as 'democracy activists,' 'falunkun (Falungong) elements' and 'Eastern Turkistan terrorists."' The Tibetan proposal to gain control over immigration is likened to "ethnic

\footnotetext{
${ }_{10}$ Tibetan Memorandum, supra note 3.

11 Address at the Press Conference Press Conference by the State Council Office," Beijing, Nov. 10, 2008 (hereinafter "State Council Address") (address given by Mr. Zhu Weiqun, Executive Vice-Minister of the United Front Work Department of the CPC Central Committee). The United Front Work Department is responsible for national minority affairs.
} 
cleansing." The exile government is said to be a "small group of splittists." The meetings were essentially damage control, with some international public relations objectives, mostly aimed at persuading the Dalai Lama to "give up his splitting activities." The State Council Address declared, "We never discussed the so-called "Tibet issue" and will "never make a concession." Demonstrating even greater insensitivity to Tibetan concerns, in January 2009 the PRC created a new holiday to celebrate the "liberation" of Tibet which they have labeled "Serfs Emancipation Day."12

After the State Council Address the Dalai Lama's representative published a note responding to these various criticisms and emphasizing that the type of self-governing autonomy sought in the Tibetan Memorandum is consistent with both the PRC Constitution and the practice of autonomy around the world — that posed no risk to the sovereignty of the country. ${ }^{13}$ They emphasized that there was a difference of opinion on history and that this should be no "obstacle to seeking a mutually beneficial common future within the PRC." 14 The Tibetan exile movement also convened a large Special Meeting of the Tibetans in Diaspora in Dharamsala, India in mid-November, 2008 where Tibetans expressed doubts about Chinese intentions but resolved to continue efforts at achieving genuine autonomy under the Middle-Way approach. ${ }^{15}$

Presently, things remain at an impasse, with Chinese efforts to control opposition in Tibet and isolate the Dalai Lama continuing. Offering no concessions regarding the character of autonomy, the Chinese Government in its 2009 White Paper on Tibet claims that autonomy is already provided under existing national minority laws. ${ }^{16}$ This essentially means no autonomy at all. In these discussions the Tibetan side, being the least empowered, has made the most concessions, including deference to Chinese demands regarding sovereignty. The quid pro quo for this concession is supposed to be "genuine autonomy" under a formula they have labeled the "Middle Way" approach. ${ }^{17}$ The Tibetan exile leaders clearly appreciate the relative weakness of their bargaining position. Their hope is that such autonomy will promote both democracy and human rights in Tibet. ${ }^{18}$ There is urgency to the Tibetan cause both as to ongoing repression and to secure their long-term survival. With increasing Chinese immigration into Tibet, Tibetans are concerned that the 1.3

12 "Tibet Sets 'Serfs Emancipation Day," Xinbua, Jan. 19, 2009, http://www.chinadaily.com.cn/china/2009-01/19/content_7410293.htm

${ }_{13}$ Note on the Memorandum on Genuine Autonomy for the Tibetan People, Dharamsala, India, Jam. 2010. http://www.tibetpolicy.eu/resource-center/official-documents/321-note-on-thememorandum-on-genuine-autonomy-for-the-tibetan-people

14 Ibid., p. 3.

15 Ibid., p. 2. See also, "China's Communist Regime Losing Ground," Agencies, Jan. 16, 2008. http:// news.outlookindia.com/items.aspx?artid=651926

16White Paper on "Fifty Years of Democratic Reform in Tibet" (hereinafter "2009 White Paper"), Information Office of the State Council of the PRC, March 2009, Beijing. http://www.chinadaily.com.cn/china/2009-03/02/content_7527376.htm Interview with Chinese Officials Liu Hongii (and Wang Xiaobin), Tibetology Research Center, Beijing, Aug. 25, 2006.

${ }^{17}$ The Dalai Lama began to articulate his "middle way" position in speeches in the 1980s before the US Congress and before the European Parliament. Address to Members of the United States Congress: Five Point Peace Plan for Tibet, Sept. 21, 1987; Address to Members of the European Parliament by His Holiness the Dalai Lama, June 15, 1988. See The Middle-Way Approach, A Framework for Resolving the Issue of Tibet, Department of Information and Public Relations, CTA Dharamsala, 2006. http:/ / www.tibet.net/en/index.php?id=115\&rmenuid=11

${ }^{18}$ Interview with HH the Dalai Lama, Dharamsala, India, Aug. 9, 2006. 
billion Chinese may eventually swamp the 5.5 million Tibetans in the vast mountainous regions of Tibet, leaving them a minority in their own land. ${ }^{19} \mathrm{By}$ some estimates this has already happened in the Tibetan cities. ${ }^{20}$ The spate of Tibetan self-immolations in 2011 and 2012 have added urgency to this impasse.

\section{Historical Claims and Present Practice in Tibet}

While the Dalai Lama has gone to great lengths to avoid a discussion of Sino-Tibetan history in his formal discussions with the Chinese Government, history has lurked in the background of nearly all Chinese claims. The Dalai Lama takes the view that agreement on history is not possible without misrepresentation, as he proclaims a willingness to work out an autonomy arrangement in the shadow of the present reality. China, on the other hand, has not been shy about reinterpreting history to justify present practice, especially when there are doubts about the legitimacy of its position. This has led it to advance a claim of ancient title and "liberation" with respect to Tibet that the Dalai Lama disputes. At a general level this dispute appears less a battle over the historical narrative than its interpretation. There are two parts to this dispute: historical title and present practice.

\section{"Tibet has been an inseparable part of China since ancient times." 21}

Assessing the Historical Sino-Tibetan Relationship. Though Chinese officials are fond of repeating the above statement, a closer look reveals a more nuanced story and hardly one that would sufficiently justify present-day sovereignty. 22 The general disrepute of imperial claims would alone call into question presentday sovereignty claims based on historical empire. But the factual record of the Tibetan case raises further question, as Chinese efforts at imperial conquest met Tibetan resistance for nearly a thousand years. This historical record does highlight the special character of the historical Sino-Tibetan relationship and may offer a yardstick by which to assess current autonomy obligations.

Imperial China often faced external threats on its western borders and attempted to neutralize these threats by conquering and assimilating its neighbors. Though Tibet was sometimes a target of such efforts, its remote mountain location made it less of a threat and inhibited Chinese efforts at conquest. After Tibet's own imperial age during the Chinese Tang Dynasty, it rarely posed sufficient threat to justify a costly conquest and direct rule. ${ }^{23}$ Rather, a loose imperial association prevailed. It was only during the last Chinese dynasty, the Qing, in the eighteenth and nineteenth centuries, that

19 Tabulations on Nationalities of 2000 Population Census of China (Beijing: Nationalities Publishing House, 2003). Available at http://www.purpleculture.net/tabulation-on-the-2000population-census-of-the-peoples-republic-of-china-3-volumes-p-753/

20 See June Teufel Dreyer, "Economic Development in Tibet Under the People's Republic of China," in Barry Sautman and June Teufel Dreyer, eds. Contemporary Tibet: Politics, Development and Society in a Disputed Region (London: M.E. Sharpe, 2006), at pp. 129-151, 139; Anne-Marie Blondeau and Katia Buffetrille, eds. Authenticating Tibet, Answers to China's 100 Questions (Berkeley: University of California Press, 2008) (comments by Andrew M. Fischer), pp. 144-151.

212009 White Paper, supra note 17.

${ }^{22}$ Eliot Sperling, The Tibet-China Conflict: History and Polemics (Washington: East West Center, Policies Studies 7, 2004).

${ }^{23}$ See Christopher I. Beckwith, Tibetan Empire in Central Asia, 24, 167 (1987). 
military invasion and imperial occupation sometimes occurred. Even then Tibet was treated as a vassal state and part of China's external empire subject to indirect rule. ${ }^{24}$ Eliot Sperling identifies China's claim that Tibet was always an inseparable part of China as a late twentieth century invention. ${ }^{25}$

Present-day Chinese accounts usually date China's claimed incorporation of Tibet to the Mongol-ruled Yuan Dynasty (1270-1368). The Tibetan abbot Sakya Pandita is reported to have subordinated Tibet to the emerging Mongol Empire in 1247AD. With some initial Tibetan resistance, the Mongols invaded and establish administrative control in 1267. It was subsequent to this in 1270 that the Mongol King, Kubilai Khan, proclaimed the Yuan Dynasty in China. Even then China was administered separately from Tibet among the Mongol's conquest. ${ }^{26}$

Warren Smith describes a carefully calibrated diplomatic relationship from the Yuan Dynasty forward between China's emperors and ruling Tibetan lamas. Imperial attempts at subordination would be matched with Tibetan resistance. ${ }^{27}$ In the Yuan Dynasty, leading Tibetan lamas served in a religious advisory role for the Mongol emperors - a role characterized by the Tibetans as a Cho-yon or patron-priest relationship. ${ }^{28}$ During the succeeding Chinese Ming Dynasty (1368-1644) this relationship persisted, though the Ming court seemed to value Tibetan lamas more for their intermediary role in dealing with the still threatening Mongols. The succeeding Manchu dominated Qing Dynasty (16361910) featured the highest level of Chinese intervention and sometimes conquest in Tibet, though no serious incorporation of a Tibet that remained separate from China. Complex interplay and protocol would offer the emperor's support for rule in Tibet by the Gelugpa Buddhist sect under the Dalai Lama.29 In the eighteenth century, the expanding Qing intruded more and more on Tibetan autonomy. By 1720, under the Emperor Kang Hsi, the Qing occupied and ruled Tibet, though the Qing garrison was withdrawn when he died in 1722. Such occupation was restored later and off and on in the decades to follow. During its occupations, to advance its efforts at indirect rule the Qing set in place a permanent government under a Tibetan Kashag or council. The Qing was also represented in Lhasa by its Amban. Qing control always involved at most indirect imperial rule, with central Tibet considered part of the Qing's "exterior empire." 30

From 1911 until the PRC occupation in 1950, Tibet was de facto independent. To justify their invasion and occupation, Chinese officials claim Tibet during this period was hopelessly feudal and savage. ${ }^{31}$ One doubts that

\footnotetext{
${ }^{24}$ Pamela Crossley, A Translucent Mirror: History and Identity in Qing Imperial Ideology (University of California, 1999) at 327-336; Sperling, supra, note 24, at 28-30. Both Crossley and Sperling note that these areas fell not under the Qing civil government but under the Court of Colonial Affairs (lifan yuan).

25 Ibid., p. 28.

${ }^{26}$ Warren W. Smith, Jr., Tibetan Nation: A History of Tibetan Nationalism and Sino-Tibetan Relations (Boulder, Colo.: Westview, 1996), pp. 83-100.

27 Ibid.

${ }^{28}$ Sperling, supra note 23, pp. 30-31.

${ }^{29}$ Ibid. pp. 111-112. The title "Dalai Lama" was introduced during the Ming Dynasty by a Mongol leader Altan Khan, designating Sonam Gyatso, the abbot of the Drepung monastery, the third Dalai Lama. Anne-Marie Blondeau and Katia Buffetrille, eds. Authenticating Tibet, supra, note 21, pp. 35-36. The word Dalai derives from the Mongolian word Tale, for oceans.

${ }^{30}$ Smith, Tibetan Nation, supra note 27, pp. 121,134-138, 145, 151.

312009 White Paper, supra note 3.
} 
feudal Tibet suffered from any worse conditions than its Asian neighbors. Commentators contest recent Chinese claims of systematic savagery and serfdom. ${ }^{32}$ Even Melvyn Goldstein, who is often cited in Chinese official accounts, notes that Tibetan serfs "were not necessarily downtrodden." 33 It seemed that Tibet had a traditional land-based economy with hierarchical social structures that are not uncommon in such systems. ${ }^{34}$ At this time, Tibet also began the first stages of political modernization. With a council or cabinet called the Kashag in place since the late Qing Dynasty, Tibetans had in the 1860s introduced a national assembly or Tshongdu, which included representatives of Lhasa's monasteries and secular officials. ${ }^{35}$ In recent Tibetan exile a form of liberal constitutional democracy has emerged, including universal suffrage in the exile community, a directly elected prime minister served by a cabinet or Kashag, a Supreme Justice Commission, and an elected Assembly of Tibetan People's Deputies. ${ }^{36}$ The Dalai Lama has recently withdrawn from temporal rule in favor of the elected Prime Minister, a situation he promises will persist in some agreed form in an autonomous Tibet. ${ }^{37}$

The period of de facto independence also witnessed the introduction of the language of modern statehood and sovereignty. In negotiations with Tibet and British India, Republican Chinese officials generally acknowledged that Tibet had a special status with only Chinese indirect rule. In negotiations at Simla, India in 1913, the British advanced a notion, similar to that which China had accepted for Mongolia, of inner and outer Tibet. This distinguished a largely independent central Tibet under Chinese suzerainty from a subordinate Eastern Tibet under Chinese sovereignty. All parties initialed the Simla Convention, accepting this view, though the Chinese ultimately did not ratify it, as they were dissatisfied with the stipulated boundary between inner and outer Tibet. ${ }^{38}$ In various other negotiations in the 1930s, China acknowledged Tibet's high degree of autonomy under nominal Chinese rule. The United States and Britain early on tended to characterize Chinese imperial territorial claims as suzerainty. ${ }^{39}$

As the Dalai Lama explains it, when the People's Liberation Army (PLA) invaded Tibet in 1951, he faced an offer he could not refuse for Tibet to

\footnotetext{
32 See Anne-Marie Blondeau and Katia Buffetrille, eds. Authenticating Tibet (comments of Robert Barnett), supra note 21, pp. 81-84.

${ }^{33}$ Melvyn C. Goldstein, A History of Modern Tibet, 1913-1951 (University of California Press, 1989), p. 5.

${ }^{34}$ See Anne-Marie Blondeau and Katia Buffetrille, eds. Authenticating Tibet (comments of Katia Buffetrille), supra note 21, at pp. 293-298.

35 Ibid., pp. 10-31.

${ }^{36}$ Lobsang Sangay, “Tibet: Exiles Journey,” Journal of Democracy, Vol. 14, No. 3 (2003), pp. 119130.

${ }^{37}$ Guidelines for Future Tibet's Polity and the Basic Features of the Constitution, Feb. 26, 1992 http://www.tibet.net/en/index.php?id=101\&rmenuid=11 ; The Middle-way Approach, supra note 18. The 2011 election in the Tibetan diaspora resulted in election of legal academic Lobsang Sangay as the first lay Prime Minister or Kalon Tripa. Abhishek Madhukar, "Exiled Tibetans elect political heir to Dalai Lama, Reuters," April 27, 2011.

38 Goldstein, supra, note 34, pp. 68-80, 832-841.

39 "(A) distinctive element of the feudal suzerainty relationship is that the suzerain holds the source of the governmental authority of the vassal state whose ruler he grants the right to exercise the authority autonomously," Michael C. van Walt van Praag, The Status of Tibet (Boulder: Westview Press, 1987), pp. 105-06. See also United States Policy Concerning the Legal Status of Tibet, 1942-1956, Historical Division, Department of State, Research Project No. 403, November, 1957, US National Archives 793B.oo/11-157.
} 
become part of the PRC.40 With weak international support to do otherwise, he accepted a Seventeen-Point Agreement "on Measures for the Peaceful Liberation of Tibet." 41 The Chinese, at the time, appeared more concerned with gaining territory and resisting outside imperialism than with saving Tibetans from feudal poverty. As the only treaty-like agreement with any of its purported national minorities, the 17-point agreement acknowledged the special status of Tibet and promised autonomy under Tibet's indigenous system of self-rule. Early on China failed to keep these special commitments, pushing Tibet toward "democratic reform."

Chafing under the thumb of their new cadre rulers in March of 1959 Tibetans rebelled and the Dalai Lama fled Tibet. ${ }^{42}$ This brought to an end centuries of Tibetan self-rule. On March 28, 1959, after the Dalai Lama's departure, China dismissed the local government and for the first time in history established direct Chinese rule over all of Tibet. The Preparatory Committee for the Tibet Autonomous Region (PCTAR), which had been established under the Dalai Lama's earlier formal chairmanship, was declared the official governing body. ${ }^{43}$ In September 1965 the Tibet Autonomous Region (TAR) was proclaimed under the first People's Congress of the TAR. Under the national minority laws, Tibet no longer enjoys a special status, being lumped together with fifty-five designated "national minorities."

The PRC's Practice of Autonomy in Tibet. China's national minority autonomy policies applied in Tibet and throughout the country are promulgated in the current 1982 PRC Constitution ${ }^{44}$ and in the Law on Regional National Autonomy (LRNA) passed in 1984, and revised in 2001.45 Article 4 of PRC Constitution provides that, "Regional autonomy is practiced in areas where people of minority nationalities live in concentrated communities." Under LRNA Article 15 autonomous areas carry out their role "under the unified leadership of the State Council and shall be subordinate to it." The LRNA promises national minority autonomy in respect of language, education, political representation, administrative appointments, local economic and financial policies, and the use of local natural resources. Effective exercise of such promised autonomy is in doubt. These laws are narrowly applied and allow substantial intrusion of central control and the national political system into local affairs. They contrast sharply with the flexible approach under PRC Constitution Article 31, as applied in Hong Kong and Macau.

The 1982 PRC Constitution, passed during China's liberalizing phase, appears to offer enhanced local autonomy. Along with the LRNA, it includes the power, subject to higher approval, to enact "regulations on the exercise of autonomy (ziribi tiaoli) and other separate regulations (danxing tiaoli) in light of

\footnotetext{
40 Dalai Lama, Freedom in Exile, The Autobiography of the Dalai Lama (HarperCollins Publishers, 1991), p. 64; Goldstein, supra note 34, pp. 798-803.

${ }^{41}$ Seventeen-point Agreement, supra note 4. See Goldstein, supra note 34, p. 759-772.

${ }^{42}$ Dalai Lama, supra note 41, p. 136.

43 Preparatory Committee for the Tibetan Autonomous Region (PCTAR), Established in April 1956.

${ }^{44}$ PRC Constitution (1982), Articles 4, 59, 65, 89 and 112-122.

http://english.peopledaily.com.cn/constitution/constitution.html

${ }^{45}$ Law of the People's Republic of China on Regional National Autonomy (hereinafter LRNA), 1984, revised 2001. http://www.china.org.cn/government/laws/2007-04/13/content_1207139.ht
} 
the political, economic and cultural characteristics." 46 "Regulations on the exercise of autonomy" have the status of a sub-constitution or basic law and it is expected that one such regulation will be enacted in each autonomous area. ${ }^{47}$ The required higher approval must typically come from the next higher level of government, for autonomous regions the Central Government and for autonomous prefectures and counties the provincial government. None of the PRC's five autonomous regions: Tibet, Xinjiang, Inner Mongolia, Guangxi, and Ningxia, have received approval for such basic regulation on the exercise of autonomy. The one attempt at enacting a basic regulation on the exercise of autonomy in the Tibetan Autonomous Region (TAR) went through 15 drafts and was eventually abandoned without being submitted to the State Council.48 Various autonomous prefectures and counties have received approval from provincial governments for basic autonomy laws that largely track the LRNA content. Autonomous regions and other areas have enacted many "separate regulations." ${ }^{49} \mathrm{~A}$ third category would be ordinary laws unrelated to autonomy, which do not require such higher approval. ${ }^{50}$

Chinese communism and Communist Party (CCP) control offers an even more daunting challenge to autonomy. This is especially evident in the legislative drafting process. Chunli Xia describes a complex system of CCP oversight of the legislative drafting process with numerous approvals required from various CCP party committees at each stage of the process. ${ }^{51}$ Given the center's control over the CCP and the fact that top party officials always come from the center there is little room for local legislative initiative. ${ }^{22}$ The imposition is further bolstered by the party's Marxist ideology, which denigrates Tibetan claims by denying the essential character of China's policies in Tibet. The CCP characterizes the 1950 occupation of Tibet as "liberation" and the institution of CCP rule as "democratic reform." This Marxist logic views colonialism as only a product of capitalist exploitation. Since China never reached the stage of full capitalist development it could not have colonized Tibet. Instead, China "liberated" the exploited classes of Tibet under a Chinese "internal multinational system," in a "common program" of local autonomous rule. ${ }^{53}$ Autonomy was merely a temporary solution on the path to ultimate assimilation. ${ }^{54}$ The CCP clearly envisioned that "the local Government of Tibet

\footnotetext{
46 PRC Constitution (1982), supra note 45, Article 116; LRNA, supra note 47, Article 19. Such provision is repeated in Article 66 of the Legislative Law.

47 Ibid., p. 10.

48 Yash Ghai and Sophia Woodman, "Unused Power: Contestation Over Autonomy Legislation in the PRC," Pacific Affairs, Vol. 82/1, 2009, pp. 29-46, at 39-40.

49 Separate regulations are made by autonomous legislative bodies on specific topics such as language, marriage, family planning, etc.

50 See Chunli Xia, Autonomous Legislative Power in Regional Ethnic Autonomy of the People's Republic of China: The Law and the Reality," in J. Oliveira and P. Cardinal, eds., One Country, Two Systems, Three Legal Orders: Perspectives of Evolution (Berlin and Heidelberg: Springer-Verlag, 2009), pp. 541-564 (citing Organic Law of the People's Republic of China, Article 7 and the Legislative Law, Article 63).

${ }^{51} \mathrm{Ibid}$.

52 See Anne-Marie Blondeau and Katia Buffetrille, eds. Authenticating Tibet (comments by Thierry Dodin), supra note 21, pp. 191-196.

${ }^{53}$ Common Program of the Chinese People's Political Consultative Committee (1949).

${ }^{54}$ Warren W. Smith, jr., China's Tibet, supra note 2, at 233. Chinese officials cite advanced technology and modern communications to justify direct rule. Interview with Liu Hongji, supra note 17 .
} 
should carry out "reform" voluntarily." 55 Such a system was, in fact, imposed after the 1959 uprising when the Dalai Lama fled.

After the 1959 Tibetan uprising, all forms of traditional political structure were quickly eliminated. The indigenous form of government promised in the 1951 Seventeen-point Agreement did not survive. The replication of the national political structures in minority areas has made them highly susceptible to top-down central administrative control. The Cultural Revolution (1966-1976) was an especially severe period of hard-line class struggle and massive cultural destruction across China. In the early 1980s, after Chinese Premier Hu Yaobang observed especially dire conditions in Tibet, a remorseful China briefly pursued a policy of liberalization. As Tibetans became more outspoken in the slightly more liberal environment this was followed by even greater repression and martial law, as hardliners in the Beijing regime concluded that liberalization had encouraged greater resistance. In the recent decade, a policy of cracking down on political support for the Dalai Lama has included so-called "patriotic education" and greater emphasis on economic development under which Chinese immigration has been favored. ${ }^{56}$ Today only Hong Kong and Macau retain a distinctive form of local self-rule.

Chinese repression has taken many forms, including military occupation and crackdowns, the sacking and razing of Buddhist monasteries, suppression of religion, coerced "reeducation" of monks and nuns, imprisonment of dissidents, and the forced relocation of rural dwellers and herders to more populated areas. Monks and nuns have especially resisted coercion to renounce the Dalai Lama. ${ }^{57}$ Popular dissent and rebellion famously arose in 1959, 1989 and 2008. Increased tensions in Tibet, most recently evident in a rash of more than thirty selfimmolations over the past two years, bear out the continued Tibetan frustration with Chinese policies. 58

Both the Chinese government and its critics have issued reports on Chinese policies in Tibet. The March 2009 Chinese White Paper on "Fifty Years of Democratic Reform in Tibet" highlights favorable statistics on Tibetan participation in autonomous governance, including: Tibetans and other minorities holding 94 percent of the seats in local people's congresses; a 96.4 percent voter turnout rate for participation in the electoral process; Tibetan and other ethnic minority deputies holding 77 percent of the staff positions in state organs at the regional, prefectural and county levels; and a claim of Tibetan occupation of the top positions of various autonomous governments and standing committees. ${ }^{59}$ At the time of the report 12 of the 20 deputies from the TAR to the National People's Congress were Tibetan. The report states that the

\footnotetext{
552009 White Paper, supra note 17, p. 1.

${ }^{56}$ Warren W. Smith, Jr., “China’s Policy on Tibetan Autonomy," East-West Center Washington Working Papers, No. 2, October 2004.

${ }^{57}$ Interview with President, Gu Chu Sun Movement of Tibet (Association of former Political Prisoners), Dharamsala, Aug. 3, 2006; Interview of "Singing Nun" Renchen Choeky, Dharamsala, Aug. 4, 2006 (Sentenced to prison for demonstrating in protest in Lhasa; and sentenced again while in prison when 18 nuns produced a singing recording that was smuggled out)

58 "Teen sets himself on fire 'for Tibet," South China Morning Post, Oct. 17, 2011, p. A7; Ng Tzewei, “Tibetan Nun Burns to Death," South China Morning Post, Oct. 19, 2011, p. A6.

592009 White Paper, supra note 17.
} 
Tibetan language is taught in the schools, and widely used along with the Chinese language- though critics worry this is mostly at the primary level. ${ }^{60}$

Even that has come under threat, with recent reports of Tibetan demonstrations against reported Chinese efforts in Qinghai autonomous areas to replace Tibetan with Chinese as the primary language of instruction in primary schools. ${ }^{61}$ The Chinese report also emphasizes China's contribution to Tibet's economic development, though critics worry that these policies benefit Chinese more than Tibetans. ${ }^{62}$ The bulk of the report emphasizes China's "liberation" of Tibet and its "democratic reform." Though the liberation was stated to be from "foreign imperial forces," the text of the report lays greater empirical emphasis on liberation from Tibetans themselves, accusing the traditional Tibetan elites of horrific feudal practices. No attempt is made to explain why China should assume the role of modernizing Tibet. The claimed democratic reform is not much explained, overlooking China's own lack of democratic reform.

A 1997 report of the International Commission of Jurist (ICJ) notes that while "Tibetans are in positions of nominal authority, they are often shadowed by more powerful Chinese officials" and that "every local organ is shadowed by a CCP committee or "leading group."”63 A 2007 report by Minority Rights Group International and Human Rights in China highlights several deficiencies, including the centralization of power in the top leadership of the CCP; the above concerns with the law-making process, Chinese dominance of CCP leadership in minority areas, including Chinese officials from the center always holding the top CCP post, and the lack of real power at the local level. ${ }^{64}$ Of particular concern for the deeply religious Tibetan nationality, is a CCP rule that bars party members from practicing Tibetan Buddhism and a recently added rule that cadres withdraw their children from Tibetan schools in India. ${ }^{65}$ Particularly puzzling has been the formal claim by the avowedly atheist Chinese government to choose the next reincarnation of the Dalai Lama and other leading lamas, which recently moved the Dalai Lama to issue his own formal statement making clear his own plans for reincarnation or emanation challenging any Chinese official role in this. ${ }^{66}$

\footnotetext{
${ }^{60}$ See Anne-Marie Blondeau and Katia Buffetrille, eds. Authenticating Tibet (comments by Amy Heller and Anne-Marie Blondeau), supra note 21, p. 235.

${ }^{61}$ Edward Wong, "Tibetans in China Protest Proposed Curbs on Their Language," New York Times, Oct. 22, 2010.

62 Anne-Marie Blondeau and Katia Buffetrille, eds., Authenticating Tibet, supra, note 21 (comments by Andrew M. Fischer), pp. 250-277. Fischer worries that the current subsidies tends to benefit Chinese officials and large Chinese construction companies, while creating dependency-what he calls the boomerang effect. Ibid., p. 269. Fischer sees greater productivity if Tibetans are left to traditional herding and farming. Ibid., p. 275.

63 Tibet: Human Rights and the Rule of Law (Geneva: International Commission of Jurists, 1997), pp. 14-21.

64 Human Rights in China and Minority Rights Group International, China: Exclusion, Marginalization and Rising Tension (Minority Rights Group International, 2007). Available at bttp:// brichina.org/public/PDFs/MRG-HRIC.China.Report.pdf.

${ }^{65}$ Kristine Kwok, "Officials to be sacked for sending their children to 'Dalai Lama Schools," South China Morning Post, July 18, 2006.

${ }^{66}$ Statement of His Holiness the Fourteenth Dalai Lama, Tenzin Gyatso, on the Issue of His Reincarnation, Sept. 24, 2011. http://dalailama.com/messages/tibet/reincarnation-statement For the Beijing response, see Zhuang Pinghui, "We choose next Dalai Lama says Beijing," South China Morning Post, 27 Sept.2011.
} 


\section{International Legal Standards}

Self-determination of peoples is grounded in the UN Charter and in the international human rights covenants, though these sources offer little guidance on who are the peoples entitled to such right. International law generally distinguishes between external and internal rights of self-determination. ${ }^{67}$ When the external right, which is thought to include a right of secession, is effectively denied, justified or not, then the internal right may be all that survives. ${ }^{68}$ This typically involves some notion of autonomy, though autonomy has not enjoyed very strong protection in international law. ${ }^{69}$ It may be argued, however, that in two circumstances autonomy becomes effectively internationalized: 1) when it is the consequence of treaty arrangements or 2) when it arises out of the denial of rights of self-determination, especially of indigenous peoples. The Tibet case includes both. The Seventeen-point Agreement reflects a treaty arrangement and Tibetans appear to be indigenous people or at least similarly situated.

For indigenous populations, human rights, self-determination and autonomy acquired greater international traction in the 2007 UN Declaration on the Rights of Indigenous Peoples. ${ }^{70}$ The Declaration provides the substantive content of internal autonomy. While UN declarations are generally not binding as such, the nearly unanimous passage (143 to 4 with eleven abstentions) of the Indigenous People's Declaration along with its purported declaration of existing customary law may strengthen its binding effect. ${ }^{71}$ The Chinese government voted for the declaration but claims there are no indigenous peoples in China, ${ }^{72}$ claiming 5,000 years of national unity and harmony with minorities living on their own lands. ${ }^{73}$

While the UN Declaration does not define "indigenous peoples," it does specify that they exist throughout the world. ${ }^{74}$ A separate 1986 UN study

\footnotetext{
${ }^{67}$ See Declaration on the Granting of Independence to Colonial Countries and Peoples, 1960 UNGA Resolution 1514 (XV), 15 UN Gaor, Supp. (No. 16), UN Doc. A/4684 (1960), p. 66; Declarations on Principles of International Law Concerning Friendly Relations and Cooperation Among States, 1970 UNGA Resolution 2625 (XXV), Annex, 25 UN Gaor, Supp. (No. 28), UN Doc. A/5217 (1970), at 121. The Human Rights Covenants in their first article guarantee "all peoples" the right to "freely determine their political status and freely pursue their economic, social and cultural rights." International Covenant on Civil and Political Rights, December 16, 1966, 999 U.N.T.S. 171; International Covenant on Economic, Social and Cultural Rights, Dec. 16, 1966, 993 U.N.T.S. 3. As a party to the ICESCR China is bound by this.

${ }^{68}$ Reference re Secession of Quebec, (1998) 161 DLR (4th) p. 385, Supreme Court of Canada.

${ }^{69}$ D. Sanders, "Is Autonomy a Principle of International Law," 55 Nordic Journal of International Law 17 (1986); F. L. Kirgis, "The Degrees of Self-determination in the UN Era," 88 American Journal of International Law 310 (1994); Hans-Joachim Heintze, "Evolution of Autonomy and Federalism," in Oliveira and Cardinal, supra, note 51, pp. 389-408.

${ }^{70}$ UN Declaration on the Rights of Indigenous Peoples, (hereinafter "Indigenous People's Declaration)

http://www.tebtebba.org/tebtebba_files/ipr/undrip/OfficialResolution/A61L.67\%20eng.pdf ${ }^{71} \mathrm{Ibid}$. Opposing the Declaration were the United States, Canada, New Zealand and Australia. 72 "China Concerned with Protection of Indigenous Peoples' Rights," Embassy of the People's Republic of China in Switzerland, 1997/04/01, http://ch.Chinaembassy.org/eng/ztnr/rqwt/t138829.htm

${ }^{73}$ Speech of Chinese Representative Group Deputy Tong Zhihwa, Human Rights Council, $1^{\text {st }}$ Meeting, 11 th Drafting Session.

http://www.docip.org/HumanRightsCouncil/sessions1/cddh1_5.pdf .

74 There are thought to be over 370 million indigenous people worldwide. "UN adopts declaration on rights for indigenous peoples worldwide," International Herald Tribune, Sept. 13, 2007.
} 
defined indigenous peoples as "communities, $[\ldots]$ which, having a historical continuity with pre-invasion and pre-colonial societies that developed on their territories, consider themselves distinct from other sectors of the societies now prevailing[...]." 75 It also emphasized that such communities consider themselves distinct from the dominant sector. The Tibetan people, even in China's own accounts in the 2009 White Paper, clearly satisfy these criteria of distinctiveness as to language, culture and history. Whatever its legal status, this UN Declaration can clearly serve as a useful guide to measure Chinese policies discussed above.

The UN Declaration's preliminary articles emphasize demilitarization of indigenous lands; the right of indigenous people to freely determine their relationship with states; that treaties, agreements and constructive arrangements with states are matters of international concern; "the fundamental importance of the right of self-determination of all peoples, by virtue of which they freely determine their political status and freely pursue their economic, social and cultural development;" and that the right to exercise self-determination in conformity with international law shall not be denied.

The operative articles of the Declaration guarantee indigenous peoples: the right of self-determination; ${ }^{76}$ the right to autonomy or self-government in matters relating to their internal and local affairs; 77 the right to manifest, practice, develop and teach their spiritual and religious traditions, customs and ceremonies, including access in privacy to their religious and cultural sites and control of their ceremonial objects; ${ }^{78}$ the right to participate in decision making in matters which would affect their rights, through representatives chosen by themselves in accordance with their own procedures; ${ }^{79}$ the right to be consulted and prior consent through their own representative institutions before implementing state legislative and administrative measures; ${ }^{80}$ and the right to recognition, observance and enforcement of treaties, agreements and other constructive arrangements. At the same time they are guaranteed the rights protected by the various human rights treaties and covenants. China's imposition of top-down CCP control under its national political system and its weak protection of basic human rights clearly falls greatly short of these standards of indigenous self-rule.

\section{A Recommended Path Forward}

The spirit of self-determination articulated above, in conjunction with Tibet's centuries-long tradition of self-rule and autonomy, clearly calls for substantive change in China's Tibet policy. That same spirit suggests that the Tibetan indigenous leadership be consulted over the policy direction. The Tibetan Memorandum offers initial guidance. The good news is that the Chinese Constitution already offers the tools in various articles on autonomy for a

\footnotetext{
${ }^{75}$ United Nations Economic and Social Council, UN Sub-Commission on the Prevention of Discrimination and Protection of Minorities, Jose Martinez Coho, Study of the Problem of Discrimination Against Indigenous Populations, UN Doc. E/CN.4/Sub.2/1986/21/Add.8. (hereinafter "UN Working Group Report")

76 Indigenous People's Declaration, supra note 71, Article 3.

77 Ibid., Article 4.

78 Ibid., Article 12

79 Ibid., Article 18.

${ }^{80}$ Ibid., Article 19.
} 
flexible approach to the Tibet question. A flexible approach that fully implements China's national minority laws, supplemented where appropriate with guarantees already applied under the "one country, two systems" formula, can surely be judged acceptable within China's constitutional framework.

Foreign ministries concerned with this issue should encourage precisely this approach using the Tibetan Memorandum as a point of takeoff. While China has traditionally objected to foreign interference, it clearly places great stock in foreign approval of its newly claimed status as a responsible leading state. Recognition of China's status surely warrants a reciprocal right to comment on what should be expected of a leading country in respect to basic human rights. China's leading trading partners, such as the United States and Europe should use their good offices to emphasize this connection.

While the PRC Government has long taken a strident view that is hyperconcerned that relaxing its Tibet polices will threaten national security, this view seems unfounded. A confident and secure Tibetan community within China would surely offer China greater security than a distraught and downtrodden community effectively under military occupation. In the Dalai Lama, the Chinese Government faces a reasonable and influential interlocutor who may assist them greatly to address their security concerns with a workable model that would, on his agreement, be accepted by both the Tibetan and international communities. This would be especially true with a model based on the standards articulated in the UN Declaration, for which the Tibetan Memorandum is a reasonably close fit. At the same time a workable model in Tibet would offer a very useful model for addressing the Xinjiang and other peripheral problems, each with attention to the unique local character in an asymmetric association.

In some respects, China's own political reforms nationwide appear to be held hostage to its concerns about losing control over its peripheral areas. A strong repressive center is seemingly thought necessary to hold the country together. Given peripheral tensions and little success at achieving the internal political reform conducive to China's continuing development a change of approach seems warranted. As the Hong Kong model is sometimes advanced as a possible solution to the Taiwan problem, an agreeable Tibet model could be offered as a solution in Xinjiang and possibly Inner Mongolia. In addition to freeing up the path to domestic reform, these arrangements may likewise eliminate some of China's stickiest foreign policy challenges. The Hong Kong model was the product of a confident and inventive Chinese leadership. That inventiveness is again sorely needed. At present Tibet and Taiwan are problems at the heart of nearly every foreign policy outing. More magnanimous gestures by China to address these problems may open the door to China normalizing its international relations and achieving more solid international standing. While the offer of genuine autonomy in a gentler China may prove an attractive option to China's disputed peripheral communities, it would also go a long way toward easing concerns about China's rise in the world at large. 